\title{
SERVITIZATION IN MANUFACTURING INDUSTRIES
}

\author{
Ugljesa Marjanovic \\ University of Novi Sad, Faculty of Technical Sciences, Trg Dositeja Obradovica 6, 21000 Novi Sad, \\ Serbia, umarjano@uns.ac.rs
}

Keywords: product-related service, digital service, servitization

\begin{abstract}
:
The process of creating value by adding services to product offerings, or servitization, is a mature theme in the literature, flourishing in recent years. Manufacturing firms increasingly produce and provide services along with their traditional physical products. Prior research investigated the servitization in developed economies. However, the emerging industries were neglected. The purpose of this research is twofold. First, we intend to shed light on the state of service portfolio choices in Serbian manufacturing. Second, we aim to investigate the frequency of each product-related services within manufacturing. Our analysis used the Serbian dataset on 280 manufacturing firms from the European Manufacturing Survey conducted in 2015. The empirical results show that, in manufacturing firms, product-related services are under-utilized. This research also provides an in-depth understanding of the frequency of each service.
\end{abstract}

\section{INTRODUCTION}

A paradigm shift in business models is occurring in the manufacturing industry [1]. Durable goods manufacturers choose to innovate their offerings by providing services to accompany their existing products throughout the life cycle [2]. However, with the advent of new technologies (i.e. information technologies), traditional services such as maintenance and repair [3] are not enough [4]. The new trend in the manufacturing industries is digital services or digital servitization. In the literature, service strategy has a long presence through wide terminology such as servitization [5], servicizing [6], product-service systems [7], or even open service innovation [2], et cetera. Today, the presence of digital technologies has brought the transformation of service business models [8] and formed something that is called digital services. The provision of digital services, or 'Digital servitization', has become a sub-stream of service business model [9]. Digital servitization is defined as "the provision of IT-enabled (i.e. digital) services relying on digital components embedded in physical products” [9]. Digital services are different from traditional since the marginal cost of digital services is near zero and they are substitutes for traditional products [10].

Early studies reported that firms were adding service to their offerings to achieve greater performance - substantial turnover, increased profit, stronger market power, reduced risk and increased competitiveness [11], [12]. A later stream of research argues that manufacturing firms should move toward service and solution providers, or to evolve from 'goods or services' to 'goods and services', to achieve revenue growth [2], [13]-[16] or a growing share of manufacturers' revenues from services [17]. Nevertheless, not all literature found positive effect of servitization. For instance, Benedettini et 
Ugljesa Marjanovic - Servitization in manufacturing industries

al. [17] list several examples where companies start withdrawing rather than extending their service offering. They list Johnson Controls, Voith and ABB as disengaging from facilities and maintenance management contracts. Kowalkowski et al. [17] list Xerox as an example of deservitization where Xerox in 2016 withdraw their service offering and formed an independent company Conduent for the service part of their provision.

The purpose of this research is twofold. First, we intend to shed light on the state of service portfolio choices in Serbian manufacturing. Second, we aim to investigate the frequency of each product-related services within manufacturing. This research uses the analysis of the Serbian dataset on 280 manufacturing firms from the European Manufacturing Survey conducted in 2015. The empirical results show that, in manufacturing firms, product-related services are under-utilized. This research also provides an in-depth understanding of the frequency of each service.

\section{METHODOLOGY}

Data for this empirical study derive from the European Manufacturing Survey, a survey on manufacturing strategies, application of innovative organizational and technological concepts in production, and questions of digital servitization in the European manufacturing industry [19]. The EMS is administered by the Fraunhofer Institute for Systems and Innovation Research [20]. The objective of this regular, triennial questionnaire is to systematically monitor the innovation behavior of European manufacturing enterprises at the firm level. The concepts, constructs and questions are well-tested and have been agreed upon in the EMS consortium. The six-page questionnaire includes questions on innovation activity, firm and industry characteristics, and general firm data. The survey is sent out repeatedly to senior managers of firms with 20 or more employees and designed to be representative of all regions, industrial sectors covered, and enterprise sizes. The survey is conducted among manufacturing firms, addressing manufacturing sites (NACE Rev. 2 codes from 10 to 33). A non-response analysis is conducted to ensure that the sample is representative of the population. The analytical dataset includes 280 observations of manufacturing firms from Serbia. The dataset in our research is from the 2015 survey edition. The comparison of data regarding firm size and industry sector distribution between Serbian subsample, and those of other EMS countries (e.g. Croatia, Germany, Lithuania, Slovakia, Slovenia) shows no significant size bias.

Regarding descriptive statistics, the sampled firms report, on average, a firm size of 124 employees (SD = 207). In total, 107 companies are small firms (fewer than 50 employees), 140 companies are medium-sized (between 50 and 249 employees), and 32 firms are large enterprises (more than 250 employees). Firms belonging to the fabricated metal products (54 firms), food products (36 firms), and machinery and equipment n.e.c. (26 firms) sectors account for the most prominent observations in the sample. Tables 1 and 2 depict the sample distribution regarding size and industry sector.

To analyze the relationships between digital services and financial implications we employed a multivariate data analyzes.

Table 1. EMS database - distribution of firms by size.

\begin{tabular}{|c|c|c|}
\hline Firm size & $\mathrm{n}$ & $\%$ \\
\hline \hline 20 to 49 employees & 107 & 38.2 \\
\hline 50 to 249 employees & 141 & 50.4 \\
\hline 250 and more employees & 32 & 11.4 \\
\hline Total & 280 & 100.0 \\
\hline
\end{tabular}


Ugljesa Marjanovic - Servitization in manufacturing industries

Table 2. Classification on manufacturing sectors according to share on total sample.

\begin{tabular}{|c|c|c|}
\hline NACE Rev. 2 & Manufacturing industry & $\begin{array}{c}\text { Share on total } \\
\text { sample (\%) }\end{array}$ \\
\hline \hline 25 & Manufacture of fabricated metal products & 19.2 \\
\hline 10 & Manufacture of food products & 12.9 \\
\hline 28 & Manufacture of machinery and equipment n.e.c. & 9.4 \\
\hline 22 & Manufacture of rubber and plastic products & 8.4 \\
\hline 27 & Manufacture of electrical equipment & 5.7 \\
\hline 23 & Manufacture of other non-metallic mineral products & 5.3 \\
\hline 13 & Manufacture of textiles & 4.3 \\
\hline 29 & Manufacture of motor vehicles, trailers and semi-trailers & 4.3 \\
\hline 14 & Manufacture of wearing apparel & 4.3 \\
\hline 18 & Printing and reproduction of recorded media & 3.9 \\
\hline 31 & Manufacture of furniture & 3.5 \\
\hline & Other & 18.8 \\
\hline
\end{tabular}

\section{RESULTS}

Figure 1 depicts frequency of product-related services within manufacturing industry in Serbia.

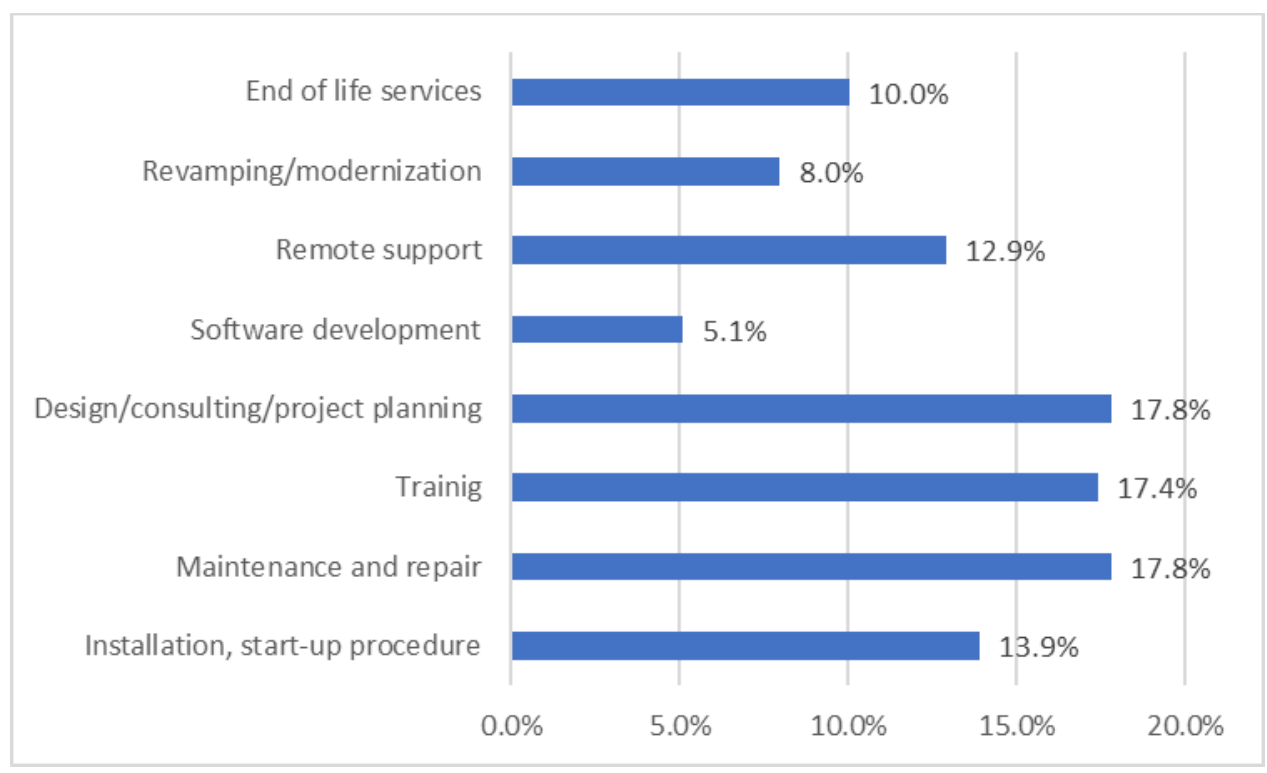

Figure 1 - Frequency of product related services (percent of total)

Results show that Serbian manufacturing firms are not utilizing product-related services in a full manner. The highest percentage of usage is below $20 \%$. In addition, results portray that design/consulting/project planning (17.8\%) and maintenance and repair (17.8\%) are two dominant type of services in the manufacturing sector. It is not clear from our data, however, whether the frequency of the two services is due to the additional managerial focus these firms received, or if, as we assume, cultural practices of customers in the market. 
Ugljesa Marjanovic - Servitization in manufacturing industries

\section{CONCLUSION}

This study examines servitization strategies of manufacturing firms. Consequently, this paper provides theoretical and practical implications on how and in what way product-related services are utilized within the Serbian manufacturing sectors. The empirical results show that, in manufacturing firms, product-related services are under-utilized. Utilization of each investigated service below 20 percentage. In addition, design/consulting/project planning and maintenance and repair are two dominant type of services in the Serbian manufacturing sector.

Managers in manufacturing firms should focus more attention on the design of new services to maximize the share of turnover from services. However, managers should be aware that not all service provisions will lead to a service business model. As suggested by Gebauer et al. [22], utilization of services in manufacturing firms represents a challenge since some manufacturers find it extremely difficult to successfully exploit the potential of an extended service business.

Our sample was collected from all manufacturing industries, and, perhaps due to the industry specificity, results could differ. Also, there are various aspects that should be taken into consideration for the assessment of product-related service (e.g. type of customer served, seasonality, and promotion). Further research is necessary to assess the experience and challenges of firms with a focus on one industry (i.e. the manufacture of fabricated metal products) and to consider different challenges in measuring the impact of digital services provided by manufacturing firms. Development of these ideas could prove especially useful for firms facing the challenges of a particular industry, showing that specific product-related services can improve their financial performance [2].

\section{REFERENCES}

[1] M. A. Cusumano, S. j Kahl, and F. F. Suarez, "Services, industry evolution, and the competitive strategies of product firms,” Strateg. Manag. J., vol. 36, pp. 559-575, 2015.

[2] I. Visnjic Kastalli and B. Van Looy, "Servitization: Disentangling the impact of service business model innovation on manufacturing firm performance,” J. Oper. Manag., vol. 31, no. 4, pp. 169-180, 2013.

[3] U. Marjanovic, B. Lalic, V. Majstorovic, N. Medic, J. Prester, and P. Iztok, "How to Increase Share of Product-Related Services in Revenue? Strategy Towards Servitization,” in Advances in Production Management Systems. Smart Manufacturing for Industry 4.0, 2018, vol. 536, pp. 57-64.

[4] U. Marjanovic, S. Rakic, and B. Lalic, "Digital Servitization: The Next 'Big Thing' in Manufacturing Industries,” in Advances in Production Management Systems. Production Management for the Factory of the Future, 2019, pp. 510-517.

[5] D. Opresnik and M. Taisch, “The value of big data in servitization,” Int. J. Prod. Econ., vol. 165, pp. 174-184, 2015.

[6] S. Rothenberg, "Sustainability Through Servicizing," MIT Sloan Manag. Rev., vol. 48, no. 2, pp. 83-91, 2007.

[7] A. Tukker, "Eight types of product-service system: eight ways to sustainability? Experiences from SusProNet,” Bus. Strateg. Environ., vol. 13, no. 4, pp. 246-260, 2004.

[8] M. Ardolino, M. Rapaccini, N. Saccani, P. Gaiardelli, G. Crespi, and C. Ruggeri, "The role of digital technologies for the service transformation of industrial companies," in International Journal of Production Research, 2018, vol. 56, no. 6, pp. 2116-2132.

[9] F. Vendrell-Herrero, O. F. Bustinza, G. Parry, and N. Georgantzis, "Servitization, digitization and supply chain interdependency,” Ind. Mark. Manag., vol. 60, pp. 69-81, 2017.

[10] S. Greenstein, “Digitization and value creation,” IEEE Micro, vol. 30, no. 4, pp. 4-5, 2010.

[11] R. Oliva and R. Kallenberg, "Managing the transition from products to services," Int. J. Serv. Ind. Manag., vol. 14, no. 2, pp. 160-172, 2003. 
Ugljesa Marjanovic - Servitization in manufacturing industries

[12] B. C. Skaggs and S. B. Droege, "The Performance Effects of Service Diversification by Manufacturing Firms.,” J. Manag. Issues, vol. 16, no. 3, pp. 396-407, 2004.

[13] A. Eggert, J. Hogreve, W. Ulaga, and E. Muenkhoff, "Revenue and Profit Implications of Industrial Service Strategies,” J. Serv. Res., vol. 17, no. 1, pp. 23-39, 2014.

[14] E. Böhm, A. Eggert, and C. Thiesbrummel, "Service transition: A viable option for manufacturing companies with deteriorating financial performance?,” Ind. Mark. Manag., vol. 60, pp. 101-111, 2017.

[15] D. Gong, S. Liu, M. Tang, L. Ren, J. Liu, and X. Liu, "Revenue sharing or profit sharing? An internet production perspective,” Adv. Prod. Eng. Manag., vol. 13, no. 1, pp. 81-92, 2018.

[16] T. Lerher, M. Borovinsek, M. Ficko, and I. Palcic, "Parametric study of throughput performance in SBS/RS based on simulation,” Int. J. Simul. Model., vol. 16, no. 1, pp. 96107, 2017.

[17] E. (Er) Fang, R. W. Palmatier, and J.-B. E. . Steenkamp, "Effect of Service Transition Strategies on Firm Value,” J. Mark., vol. 72, no. 5, pp. 1-14, 2008.

[18] O. Benedettini, M. Swink, and A. Neely, "Examining the influence of service additions on manufacturing firms’ bankruptcy likelihood,” Ind. Mark. Manag., vol. 60, pp. 112-125, 2017.

[19] B. Lalic, V. Majstorovic, U. Marjanovic, M. Delić, and N. Tasic, “The Effect of Industry 4.0 Concepts and E-learning on Manufacturing Firm Performance: Evidence from Transitional Economy," in Advances in Production Management Systems. The Path to Intelligent, Collaborative and Sustainable Manufacturing, 2017, vol. 513, pp. 298-305.

[20] Fraunhofer Institute for Systems and Innovation Research ISI, "European Manufacturing Survey,” 2019. [Online]. Available: https://www.isi.fraunhofer.de/en/themen/industriellewettbewerbsfaehigkeit/fems.html\#tabpanel-1. [Accessed: 14-Jul-2019].

[21] H. Gebauer, E. Fleisch, and T. Friedli, "Overcoming the service paradox in manufacturing companies,” Eur. Manag. J., vol. 23, no. 1, pp. 14-26, 2005. 